\title{
Seasonal effect on sexual behaviour of Kankrej bull
}

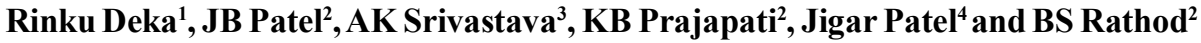

Received: 25 May 2019 / Accepted: 17 August 2019 / Published online: 28 October 2019

(C) Indian Dairy Association (India) 2019

\begin{abstract}
Studies on sexual behaviour as such, and the documented reports on the influence of seasons on these characteristics are scanty for Kankrej bulls. These indices could be successfully used in selection and culling of Kankrej bulls in the breeding programs. Hence, a study on sexual behaviour of Kankrej bull was carried out at the Semen Processing Unit; with the objective to study the seasonal effect on sexual behaviour traits of Kankrej bulls. The period of investigation was divided into three season viz., summer, monsoon and winter. Eight healthy Kankrej bulls of 4-5 years of age were selected. Weekly once semen collection was done for each bull, but only fortnightly observations of semen collection were recorded and eight collections in a season for each bull, 64 from each season and total of 192 collections, were evaluated. The mean values for different sexual behaviour traits were; temperament score (0-5 scale) $1.96 \pm 0.02$, libido score ( 0 - 9 scale) $6.20 \pm 0.12$, erection score (0-4 scale) $3.36 \pm 0.04$, protrusion score (0-4 scale) $2.90 \pm 0.02$, intensity of thrust (0-4 scale) $3.42 \pm 0.06$, reaction time $112.20 \pm 5.09$ seconds, total time taken to successful mount $165.68 \pm 6.53$ seconds and Flehmen reaction ( $0-1$ scale) $0.49 \pm 0.04$. Libido was
\end{abstract}

\footnotetext{
${ }^{1 \& 3}$ Department of Livestock Production and Management, College of Veterinary Science and Animal Husbandry, Sardarkrushinagar Dantiwada Agricultural University, Sardarkrushinagar - 385 506, Gujarat, India

${ }^{2}$ Livestock Research Station, Sardarkrushinagar Dantiwada Sardarkrushinagar - 385 506, Gujarat, India

${ }^{4}$ Krishi Vigyan Kendra, Arnej, Anand Agricultural University, Anand, Gujarat 282230, India

AK Srivastava $(\square)$

Department of Livestock Production and Management, College of Veterinary Science and Animal Husbandry,

Sardarkrushinagar Dantiwada Agricultural University, Sardarkrushinagar 385 506, Gujarat, India

E-mail: aksrivastavavet@gmail.com

Mobile: 9427765668
}

significantly $(\mathrm{P}<0.05)$ higher in June $(7.31 \pm 0.35)$ and July (7.25 \pm 0.41$)$ months, as compared to rest of the months. Significantly lower libido was observed in October $(5.31 \pm 0.45)$ and November $(5.13 \pm 0.34)$ months. Libido score was significantly $(\mathrm{P}<0.05)$ higher during summer $(6.70 \pm 0.18)$ season as compared to winter $(5.70 \pm 0.19)$. However, libido score during monsoon (6.20 \pm 0.23$)$ was non-significant with both summer and winter seasons. Seasonal variation was non significant for other sexual behaviour traits viz., temperament, erection, protrusion, intensity of thrust, reaction time, total time taken to successful mount and Flehmen reaction. Positive correlation was observed between libido score and reaction time; erection score with protrusion score and intensity of thrust; protrusion score with intensity of thrust and reaction time with total time taken to successful ejaculation. It was concluded that, Kankrej bull have good sexual behaviour throughout the year, however, sexual behaviour was more intensive in summer months.

Keywords: Erection, Kankrej bull, Libido, Reaction time, Sexual behaviour, Season

\section{Introduction}

The demand for elite indigenous animals is getting very high in India over the recent years owing to their milk quality, adaptability to harsh environment and survivability on poor quality feed and fodder resources. Kankrej is a dual purpose breed of zebu cattle. It derives the name from its native tract i.e. Kankrej taluka of Banaskantha district, North Gujarat. They are well adapted to the geo-climatic conditions of Saurashtra and Kutch, have immense draught power and are known for yielding good quantity of milk with high fat content even in stress conditions.. The cows are average milkers and average yield is about $1738 \mathrm{~kg}$ per lactation, average calving interval is around 450 days and fat content ranges from 2.9 to 4.2 percent (NBAGR, 2018) under farm conditions. Whereas, average standard (305days) lactation yield was 2627 liters with average calving interval of 447 days has been achieved in Kankrej cows maintained at Livestock Research Station, Sardarkrushinagar Dantiwada Agricultural University, Gujarat (Anonymous, 2017) with maximum milk production of an individual animal as $6250 \mathrm{~kg}$ in a standard lactation (Patel et al. 2017). These animals have sustained well in arid and semi-arid 
condition and can be improved for better milk production. The populations of the Indigenous breeds of cattle are progressively diluted due to crossbreeding programme and mechanization of agriculture in India. The demand for frozen semen of elite indigenous bulls is increasing throughout the country. To achieve the optimum target of quality frozen semen production with better fertility breeding soundness evaluation of bulls is important, for which sexual behaviour of breeding bulls need to be studied (Solanki et al. 2019).

Artificial insemination (AI) has been proved as the most rapid and cost effective method to improve productivity of livestock. To meet the increasing demand for semen from superior sires, the AI industry has to optimize the harvest of quality spermatozoa per dose of semen. Joshi and Kharche (1992) reported that the intensity of sexual expression not only reflects the sex drive (libido), but also the seminal attributes of bull. According to Chenoweth (1994) assessment of libido and semen evaluation, both represent important aspects of bull fertility. As fertility is hereditable trait, bulls must be exceptionally fertile. Sexual behaviour is a very complex phenomenon, controlled by endocrine constitution of an animal, influenced by social environment, sensory capacities and sexual stimuli (Naskar and Nagpaul 2005). Cattle are not considered as seasonal breeder. However, different seasons of the year may affect performance of bull through macro or micro climatic factors as well as vegetation. Previous studies on effect of season on sexual behaviour and semen production have shown contradictory results, often due to poorly defined environmental conditions, type of animal or breed. Hence the present study was designed so as to acquire pertinent information on the important aspects of sexual behaviour in bull during different seasons of the year, which may facilitate in better management and utilization of breeding bulls.

\section{Materials and Methods}

The study was carried out at Semen Processing Unit, Livestock Research Station of Sardarkrushinagar Dantiwada Agricultural University, Sardarkrushinagar, Gujarat, on eight healthy Kankrej bulls of 4-5 years of age for a period of 12 months from March, 2013 to February, 2014 in three seasons. The year was divided into three seasons (Srivastava et al. 2009) based on climate viz., summer (March to June), monsoon (July to October) and winter (November to February). Bulls were housed in single row shed under loose housing system and individual bull pen was provided to each bull. Feeding and watering was done as per the Minimum Standard Protocol (MSP), decided by Ministry of Agriculture and Farmer's Welfare (GOI).

Semen collection was done on sandy soil floor in the early morning. The collection floor was prepared by leveling of the area and spraying of water in evening on the previous day of collection. Mehsana buffalo bull was used as dummy animal, as the Kankrej bulls showed reluctance to act as dummy. Unlike Kankrej, Mehsana buffalo bull dummy was quite and stand steadily during semen collection. Their lower height was also an added advantage. However, it was observed that one of the bulls didn't mount on buffalo dummy and Kankrej dummy was needed for collection of semen. Weekly once semen collection was done for each bull, however only fortnightly observations of semen collection were recorded and total eight collections in a season were considered for each bull. Thus a total of 192 collections, 64 from each season were evaluated. The sexual behaviour during semen collection was recorded with the help of respective score cards.

\section{Sexual behaviour traits}

Temperament of bull while approaching the teaser animal was recorded as per the six point (1-6) Temperament score card (Table1) developed by Hearnshaw and Morris (1984) and Libido Score on a 10-point scale score card (Table 2) described by Chenoweth (1981). Erection and protruding of penis during seeking and ejaculatory thrust were observed and scored (Table 3) as described by Joshi and Kharche (1992). Reaction time was recorded (in seconds) as the time lapse between the appearance of bull to the dummy animal and its first mount or mounting attempt. The mount may or may not be successful. Total time taken to successful ejaculation was recorded as the duration of time from when a bull is brought to a dummy animal, up to mount with successful ejaculation. For recording Flehmen Reaction score of "1" was given if the bull exhibited flehmen response during semen collection, while score of " 0 " was given if no response was observed (Prajapati et al. 1999).

\section{Environmental variables}

The fortnightly mean values of maximum temperature, minimum temperature, relative humidity $(\mathrm{RH})$, and temperature humidity index (THI), during the different seasons were recorded. THI was calculated using the following formula (NRC, 1971).

$$
\mathrm{THI}=0.72(\mathrm{Twb}+\mathrm{Tdb})+40.6
$$

Where,

Twb $=$ Wet bulb temperature and $\mathrm{Tdb}=$ Dry bulb temperature

\section{Statistical analysis}

Mean values of different parameters were subjected to statistical analysis as per the procedure of CRD (Complete Randomised Design) as defined by Snedecor and Cochran (1994). To verify the association among different parameters, the correlation coefficient values were calculated. Multiple range test proposed by Duncan (1955) was used for overall comparison of treatment mean values. 


\section{Results and Discussion Weather factors}

The overall mean maximum and minimum temperature of the ambient during summer, monsoon and winter season were 37.05 and $21.67,33.12$ and 25.32 and 28.26 and $11.40^{\circ} \mathrm{C}$, respectively. In the summer season the maximum temperature of $40.53^{\circ} \mathrm{C}$ was recorded in the second fortnight of May month and the lowest minimum temperature of $13.91^{\circ} \mathrm{C}$ was recorded in the first fortnight of March. During monsoon season the maximum temperature of $35.31^{\circ} \mathrm{C}$ was recorded in the first fortnight of September and the lowest minimum temperature of $20.84^{\circ} \mathrm{C}$ was recorded in the second fortnight of October. In winter season the maximum temperature of $31.53^{\circ} \mathrm{C}$ was recorded in the first fortnight of November and the lowest minimum temperature of $7.8^{\circ} \mathrm{C}$ in the first fortnight of January. Summer and monsoon season had cumulative total rainfall of 201.30 and $908 \mathrm{~mm}$, respectively, whereas, no precipitation was recorded during winter.

The morning and evening temperature humidity index during summer, monsoon and winter were 73.89 and 83.97, 76.85 and 82.35 and 58.55 and 73.90 , respectively. The highest THI in summer was recorded in evening of second fortnight of May (87.17) and the lowest was in morning of first fortnight of March (63.17). During monsoon, the highest THI was recorded in evening of first fortnight September (83.74) and the lowest was in morning of second fortnight of October (70.83), while in winter, the highest THI was recorded in evening of first fortnight of November (77.20) and the lowest was in morning of first fortnight in January (53.61).
Sharma et al. (2017) classified the THI range in three groups i.e. group I having THI of 64 to 72 , Group II ( 72 to 78 ) and Group III (78 and above) and found that semen concentration decreases significantly with the increase in THI value and the observed that semen parameters were found highest at mean THI value of 68.42 for crossbred bulls. Solanki et al. (2019) reported that winter was the favourable season as compared to summer for the manifestation of sexual behaviour in Gir bulls.

\section{Sexual behaviour traits}

\section{Temperament score}

Kankrej bulls were well managed during semen collection with docile to little aggressive temperament. Average temperament score of Kankrej bulls ranged from 1.81 to 2.06 with overall mean value of $1.96 \pm 0.02$ during the months. Variation of months and seasons had no significant effect on temperament score of Kankrej bulls (Table 4 and 5). However higher values of temperament score was recorded during winter $(1.98 \pm 0.03)$ followed by monsoon (1.95 \pm 0.03$)$ and summer $(1.94 \pm 0.04)$. The bulls were docile and manageable at the time of semen collection and the score ranged from docile to little aggressive. Similar temperament scores in Sahiwal (Panwar and Nagpaul, 1989) and Gir (Solanki et al. 2019) bulls have also been reported. Temperament score recorded in the present study was, however, higher than that recorded earlier in Sahiwal bulls (Elrabie et al. 2008; Reddy and Sasikala, 2013). Nevertheless, higher temperament scores than the present ones in Karan Swiss and Karan Fries bulls (Panwar

Table 1 Temperament score card

\begin{tabular}{lll}
\hline Sr. No. & Description & Score \\
\hline 1. & Stand very quietly, offers no resistance, only casual fair switching & 00 \\
2. & Generally quiet, offers taken resistance, steady movement & 01 \\
3. & Slightly excited movement, straining and paddling, may kick & 02 \\
4. & Excited vigorous, abrupt movement, straining and paddling, may kick & 03 \\
5. & Very disturbed, frightened, wild movements, many jumps and falls down in crate & 04 \\
6. & Unmanageable and dangerous & 05 \\
\hline
\end{tabular}

Table 2 Libido score card

(Source: Hearnshaw and Morris, 1984)

\begin{tabular}{llc}
\hline Sr. No. & Description & Score \\
\hline 1. & Bull showed no sexual interest or no mounting & 00 \\
2. & One mount or mounting attempt, no service & 01 \\
3. & Two mounts or mounting attempts, no service & 02 \\
4. & More than two mounts or mounting attempts, no service & 03 \\
5. & Two mounts, one service followed by sexual interest including mounts and mounting & 04 \\
& attempts & 05 \\
6. & More than two mounts or mounting attempts and one service followed by sexual interest & 06 \\
7. & Two mounts, one service, no further sexual interest & 07 \\
8. & One mount, one service, no further sexual interest & 08 \\
9. & One mount , one service followed by sexual interest including mounts or mounting attempts & 09 \\
\hline 10. & More than two mounts and one service, no further sexual interest & \\
\hline
\end{tabular}

(Source: Chenoweth, 1981) 
and Nagpaul, 1989) and in Jersey x Sahiwal crossbred bulls (Reddy and Sasikala, 2013) have been reported. Contrary to our study Solanki et al. (2019) reported significant $(\mathrm{P}<0.01)$ effect of season on temperament score, with higher values recorded during winter than the summer season. The finding of present study is in accordance with earlier study of Prajapati et al. (1999) where they have concluded that season has no significant effect on Mehsana buffaloes and the temperament of a bull is governed mainly by genetic make-up and less affected by environmental factors.

\section{Libido score}

The Kankrej bulls were very active during semen collection and exhibited pronounced libido as evident from their score, indicating better reproductive potential. Overall mean of libido score in Kankrej bull was $6.20 \pm 0.12$, which was significantly $(\mathrm{P}<0.05)$ affected by month (Table 5). It indicated that Kankrej bulls required about two false mounts for service with no sexual interest thereafter. Libido was significantly higher in June and July months and lower during October to January months. Significantly higher libido in Kankrej bull during June and July months may be due to comfortable environment at the location of experiment as depicted by mean value of THI recorded early morning time. Exposure of animals to extreme cold in the night and early morning might have lowered the libido in these animals during winter months.

Significantly $(\mathrm{P}<0.05)$ higher libido score was recorded during summer $(6.70 \pm 0.18)$ season as compared to winter $(5.70 \pm 0.19)$.
Libido score during monsoon $(6.20 \pm 0.23)$ was comparable to both summer and winter seasons (Table 4). On the contrary to our results, significantly lower libido score was observed during the summer season (Ahmad et al. 2005) in Sahiwal and Gir bulls (Solanki et al. 2019). Mandal et al. (2008) and Mahmood et al. (2013) recorded non-significant but lower libido during summer season in Frieswal bulls and Cholistani bull, respectively, as compared to winter season. Variations in libido score by various authors might be attributed to the different managemental conditions, experimental locations and breed. The location is under semi arid zone and is characterized by cooler morning hours during summer. Higher libido in Kankrej bulls during summer months may be due to comfortable environment at during night and early morning time. Conversely, exposure of animals to extreme cold in the night and early morning during winter might have lowered the libido in these animals. Moreover, it was observed that animals became fattier in winter, which might have additional effect on lowering of libido. High humidity and temperature may be the reason for the non-significant but lower libido during monsoon season.

\section{Erection score}

The animals showed pronounced penile erection throughout the study period. The mean value of penile erection was $3.36 \pm 0.04$. Marginally higher erection score than that of the present study was noted in crossbred bulls (Joshi and Kharche, 1992), Jersey x Sahiwal crossbreds (Reddy and Sasikala, 2013). Whereas, lower mean erection scores than present study have also been reported

Table 3 Scorecard for penile erection, protrusion and thrust in breeding bulls

\begin{tabular}{llllllc}
\hline Sr. No. & Erection score & & Protrusion score & & Thrust score & Score \\
\cline { 2 - 6 } & Description & Score & Description & Score & Description & 00 \\
\hline 1. & No erection & 00 & No protrusion & 00 & No thrust & 01 \\
2. & Partial erection & 01 & Partial protrusion & 01 & Weak thrust & 02 \\
3. & Fair erection & 02 & Fair protrusion & 02 & Good thrust & 03 \\
4. & Good erection & 03 & Normal protrusion & 03 & Very good thrust & 04 \\
5. & Very good erection & 04 & Abnormal protrusion & 04 & Excellent thrust & \\
\hline
\end{tabular}

(Source: Joshi and Kharche, 1992)

Table 4 Sexual behaviour traits (Mean \pm SE) of Kankrej bulls during different seasons

\begin{tabular}{lllc}
\hline Traits & Summer $(\mathrm{n}=64)$ & Monsoon $(\mathrm{n}=64)$ & Winter $(\mathrm{n}=64)$ \\
\hline Temperament $(0-5)$ & $1.94 \pm 0.06$ & $1.95 \pm 0.03$ & $1.98 \pm 0.03$ \\
Libido $(0-9)$ & $6.70 \pm 0.18^{\mathrm{a}}$ & $6.20 \pm 0.23^{\mathrm{ab}}$ & $5.70 \pm 0.19^{\mathrm{b}}$ \\
Erection $(0-4)$ & $3.38 \pm 0.07$ & $3.42 \pm 0.07$ & $3.30 \pm 0.07$ \\
Protrusion $(0-4)$ & $2.94 \pm 0.03$ & $2.92 \pm 0.03$ & $2.84 \pm 0.05$ \\
Intensity of thrust (0-4) & $3.53 \pm 0.09$ & $3.47 \pm 0.09$ & $3.27 \pm 0.11$ \\
Reaction time(sec) & $120.14 \pm 08.24$ & $108.94 \pm 09.23$ & $107.53 \pm 08.98$ \\
Total time taken to successful & $175.20 \pm 11.00$ & $155.30 \pm 10.70$ & $166.50 \pm 12.20$ \\
ejaculation (sec) & & & $0.48 \pm 0.06$ \\
Flehmen Reaction & $0.55 \pm 0.06$ & $0.44 \pm 0.06$ & \\
\hline
\end{tabular}

Mean values having different superscript within a row differ significantly from each other $(\mathrm{P}<0.05)$ 
in Sahiwal (Mandal and Tyagi, 2004; Elrabie et al. 2008; Reddy and Sasikala, 2013) and Frieswal bulls (Mandal et al. 2008).

Variation of month (Table 5) and season (Table 4) had no significant effect on erection score of Kankrej bulls. Bhosrekar et al. (1992a and b) observed non significant seasonal variation of erection score in Murrah and Surti buffalo bull, respectively. Prajapati et al. (1999) observed significantly different erection score during all the seasons in Mehsana bulls, with maximum erection score in monsoon season. Recently, Soalnki et al. (2019) classified the year in summer and winter season and reported that erection score was significantly higher $(P<0.01)$ during winter as compared to summer season in Gir bulls. Kankrej bulls showed good erection score throughout the study indicating better sexual behaviour. Reddy et al. (2013) concluded that variation in the penile erection score might be due to the high sexual stimulation at the time of semen collection and age differences in bulls.

\section{Protrusion score}

The animals showed marked penile protrusion and the mean protrusion score was $2.90 \pm 0.02$. No significant difference of protrusion score was observed among the months and seasons (Table 4 and 5), however, higher value was observed during summer $(2.94 \pm 0.03)$ followed by monsoon $(2.92 \pm 0.03)$ and winter $(2.84 \pm 0.05)$ season. This is in line with those reported in Murrah (Bhosrekar et al. 1992a) and Surti buffalo (Bhosrekar et al. 1992b). Prajapati et al. (1999) observed significant $(\mathrm{P}<0.01)$ variation among seasons on protrusion score of Mehsana bulls, being maximum during monsoon, whereas, Soalnki et al. (2019) reported significantly higher $(P<0.01)$ during winter season in Gir bulls. The variation in the penile protrusion score might be due to the high sexual stimulation at the time of semen collection, individual preference of the bull or presence of dominant bull or adult bull (Singh et al. 2015).

\section{Intensity of thrust}

The animals showed pronounced intensity of thrust throughout the study period with mean score of $3.42 \pm 0.06$. There was no significant effect of month and season on the intensity of thrust score (Table 4 and 5). However, higher intensity of thrust was observed during summer (3.53 \pm 0.09$)$ season. Similar to our finding Solanki et al. (2019) reported non-significant effect on mean intensity of thrust in Gir bulls. Contrary to our results Bhosrekar et al. (1992a and b) observed significant seasonal effect on intensity of thrust of Murrah and Surti buffalo bulls, respectively, whereas, Prajapati et al. (1999) observed significantly lower intensity of thrust during summer season and the score were at par during monsoon and winter season. Variations in thrust score by various researchers might be attributed to the different managemental conditions, experimental locations, species and breed.

\section{Reaction time}

The bulls were slow to react and to complete ejaculation with overall mean reaction time $112.20 \pm 5.09$ seconds. Longer reaction time compared to the present study was recorded in Sahiwal (Ahmad et al. 2005), Angus, Gir, Guzerat and Nellore (Daniela et al. 2008) and Cholistani bulls (Mahmood et al. 2013). Reaction time of Kankrej bull during different months and seasons was statistically non-significant (Table 4 and 5). However, the bulls needed more reaction time during summer (120.14 \pm 8.24$)$, as compared to monsoon (108.94 \pm 9.23$)$ and winter (107.53 \pm 8.98$)$ season. This might be due to the reason that during hot season

Table 5 Sexual behaviour traits $(\mathrm{Mean} \pm \mathrm{SE})$ of Kankrej bulls during different months

\begin{tabular}{|c|c|c|c|c|c|c|c|c|c|}
\hline \multirow[t]{2}{*}{ Months } & \multirow[t]{2}{*}{$\mathrm{N}$} & \multicolumn{2}{|c|}{ Temperament Libido } & \multirow{2}{*}{$\begin{array}{l}\text { Erection } \\
(0-4)\end{array}$} & \multirow{2}{*}{\multicolumn{2}{|c|}{$\begin{array}{l}\text { Protrusion Intensity } \\
\text { of thrust } \\
(0-4) \quad(0-4)\end{array}$}} & \multirow{2}{*}{$\begin{array}{l}\text { Reaction } \\
\text { time } \\
(\text { sec. })\end{array}$} & \multirow{2}{*}{$\begin{array}{l}\text { Total time } \\
\text { taken to } \\
\text { successful } \\
\text { ejaculation (sec.) }\end{array}$} & \multirow{2}{*}{$\begin{array}{c}\text { Flehmen } \\
\text { reaction }\end{array}$} \\
\hline & & $(0-5)$ & $(0-9)$ & & & & & & \\
\hline$\overline{\text { March }}$ & 16 & $1.88 \pm 0.16$ & $6.75 \pm 0.31^{\mathrm{abc}}$ & $3.31 \pm 0.12$ & $2.94 \pm 0.06$ & $3.44 \pm 0.22$ & $97.56 \pm 8.36$ & $154.31 \pm 20.36$ & $0.44 \pm 0.13$ \\
\hline April & 16 & $2.06 \pm 0.17$ & $6.44 \pm 0.40^{\mathrm{abc}}$ & $3.38 \pm 0.13$ & $2.94 \pm 0.06$ & $3.63 \pm 0.16$ & $115.63 \pm 15.05$ & $185.00 \pm 21.98$ & $0.44 \pm 0.13$ \\
\hline May & 16 & $1.81 \pm 0.10$ & $6.31 \pm 0.35^{\mathrm{abcd}}$ & $3.44 \pm 0.13$ & $2.94 \pm 0.06$ & $3.44 \pm 0.20$ & $123.75 \pm 13.54$ & $169.88 \pm 18.44$ & $0.63 \pm 0.12$ \\
\hline August & 16 & $2.00 \pm 0.00$ & $6.19 \pm 0.39^{\text {bcde }}$ & $3.63 \pm 0.13$ & $2.88 \pm 0.09$ & $3.31 \pm 0.22$ & $131.69 \pm 26.80$ & $178.19 \pm 27.39$ & $0.50 \pm 0.13$ \\
\hline September & 16 & $2.00 \pm 0.00$ & $6.06 \pm 0.4^{\text {cde }}$ & $3.31 \pm 0.15$ & $2.88 \pm 0.09$ & $3.31 \pm 0.20$ & $93.88 \pm 10.67$ & $148.69 \pm 19.83$ & $0.50 \pm 0.13$ \\
\hline October & 16 & $1.88 \pm 0.09$ & $5.31 \pm 0.45^{\text {de }}$ & $3.44 \pm 0.13$ & $3.00 \pm 0.00$ & $3.69 \pm 0.15$ & $109.81 \pm 20.72$ & $158.00 \pm 24.70$ & $0.25 \pm 0.11$ \\
\hline November & 16 & $1.94 \pm 0.06$ & $5.13 \pm 0.34^{\mathrm{e}}$ & $3.25 \pm 0.14$ & $2.94 \pm 0.06$ & $3.31 \pm 0.15$ & $91.25 \pm 14.23$ & $145.75 \pm 19.87$ & $0.19 \pm 0.10$ \\
\hline December & 16 & $2.06 \pm 0.06$ & $5.88 \pm 0.38^{\text {cde }}$ & $3.31 \pm 0.12$ & $2.81 \pm 0.10$ & $3.19 \pm 0.23$ & $103.75 \pm 24.18$ & $159.75 \pm 30.75$ & $0.63 \pm 0.12$ \\
\hline
\end{tabular}

Mean values having different superscript within a column differ significantly from each other $(\mathrm{P}<0.05)$. 
thyroid activity is depressed, resulting in low plasma testosterone level, which prolongs the reaction time (Arthur, 1975). Similar results were reported in Sahiwal bull Ahmad et al. (2005) in Sahiwal bulls, while, significantly longer reaction time during summer has been reported in Sahiwal (Mandal and Tyagi (2004), Cholistani (Mahmood et al. 2013) and Gir (Solanki et al. 2019) bulls. However, Asmat (2002) observed significantly longer reaction time during the spring, autumn and winter seasons than the summer season in Sahiwal bulls. Reddy and Sasikala, (2013) concluded that the reason for significant variations in reaction time might be due to the age of bulls, individual preference, difference in managemental practices and variation in recording of reaction time. The results of present study confirm that zebu bulls are slower to react, which indicates the existence of differences in genetic makeup in sexual behaviour of these animals (Chenoweth et al. 1996; Daniela et al. 2008). Hence added stimulus like whistling, walking of the animal around the dummy etc. may be used in case the animal which takes longer time to react.

\section{Total time taken to successful ejaculation}

Overall mean total time taken for successful ejaculation in Kankrej bulls was recorded as $165.68 \pm 6.53$ seconds which is longer than the earlier studies in Sahiwal (Mandal and Tyagi, 2004) in Frieswal (Mandal et al. 2008) and in Jersey x Sahiwal (Sasikala and Reddy, 2013 ) bulls. However, it was not significantly affected by variation in months and seasons (Table 4 and 5). Although, the bulls took more time to ejaculate during summer (175.20 \pm 11.00$)$, followed by winter $(166.50 \pm 12.20)$ and monsoon $(155.30 \pm 10.70)$ season. Mandal et al. (2000) recorded significantly longer total time to ejaculate during summer and least during winter in Murrah bulls. However, Prajapati et al. (1999) observed significantly longer total time for successful ejaculation in monsoon season followed by winter and summer season in Mehsana bulls. The reason for significant variations in total time taken to successful ejaculation might be due to the age, breed and species of bulls; individual preference; difference in managemental practices and variation in recording time.

\section{Flehmen reaction}

Flehmen reaction was observed in single instance out of two collections. Mean frequency of Flehmen reaction recorded in the Kankrej bulls was $0.49 \pm 0.04$. Flehmen reflex exhibited by Kankrej bulls during different months and seasons (Table 4 and 5) were comparable, however mean frequency of flehmen reaction was maximum during summer $(0.55 \pm 0.06)$ followed by winter $(0.48 \pm 0.06)$ and monsoon $(0.44 \pm 0.06)$ season. Higher frequency of Flehmen's response was reported by Dias et al. (2009) whereas researchers, Mandal and Tyagi (2004); Pal et al. (2012) in Sahiwal; Mandal et al. (2008) in crossbred and Solanki et al. (2019) in Gir bulls, have reported lower frequency than present study. Prajapati et al. (1999) observed more frequent flehmen reaction during monsoon season in Mehsana buffaloes. This might be due to species difference.

\section{Correlation among sexual behavioural traits}

Correlations among various sexual behaviour traits are presented in Table 6. Temperament score had significant $(\mathrm{P}<0.05)$ low positive correlation $(\mathrm{r}=0.18)$ with total time taken to successful ejaculation. Similar report of significant correlation $(\mathrm{P}<0.05)$ between temperament score with reaction time and total time taken to successful ejaculation was recorded by Kumar (1995) in Sahiwal bull.

Highly significant positive $(\mathrm{P}<0.01)$ low correlation $(0.27)$ was observed between libido score and reaction time, which is supported by the results of Panwar and Nagpaul (1989) and Singh et.al (2015), whereas the correlation was found non-significant by Kumar (1995) and non-significant negative correlation by Pal

Table 6 Correlation coefficient of sexual behaviour traits in Kankrej bulls

\begin{tabular}{|c|c|c|c|c|c|c|c|c|}
\hline Traits & $\begin{array}{l}\text { Temperament } \\
(0-5)\end{array}$ & $\begin{array}{l}\text { Libido } \\
(0-9)\end{array}$ & $\begin{array}{l}\text { Erection } \\
(0-4)\end{array}$ & $\begin{array}{l}\text { Protrusion } \\
(0-4)\end{array}$ & $\begin{array}{l}\text { Intensity } \\
\text { of thrust } \\
(0-4)\end{array}$ & $\begin{array}{l}\text { Reaction } \\
\text { time (sec.) }\end{array}$ & $\begin{array}{l}\text { Total time } \\
\text { taken to } \\
\text { successful } \\
\text { ejaculation (sec.) }\end{array}$ & $\begin{array}{l}\text { Flehmen } \\
\text { reaction }\end{array}$ \\
\hline Temperament $(0-5)$ & 1.00 & & & & & & & \\
\hline Libido (0-9) & 0.08 & 1.00 & & & & & & \\
\hline Erection $(0-4)$ & -0.09 & -0.01 & 1.00 & & & & & \\
\hline Protrusion(0-4) & -0.04 & -0.06 & $0.37 * *$ & 1.00 & & & & \\
\hline $\begin{array}{l}\text { Intensity of } \\
\text { thrust }(0-4)\end{array}$ & 0.03 & -0.09 & $0.23 * *$ & $0.45 * *$ & 1.00 & & & \\
\hline $\begin{array}{l}\text { Reaction time } \\
\text { (sec.) }\end{array}$ & 0.09 & $0.27 * *$ & -0.07 & 0.01 & -0.12 & 1.00 & & \\
\hline $\begin{array}{l}\text { Total time taken } \\
\text { to successful } \\
\text { ejaculation }(\mathrm{sec} .)\end{array}$ & $0.18^{*}$ & 0.09 & -0.04 & 0.06 & -0.12 & $0.82 * *$ & 1.00 & \\
\hline Flehmen reaction & 0.06 & 0.04 & 0.05 & -0.06 & -0.10 & 0.10 & 0.07 & 1.00 \\
\hline
\end{tabular}

* Significant at $\mathrm{P}<0.05$ and $* *$ significant at $\mathrm{P}<0.01$ 
et al. (2012). Kumar (1995) observed in Sahiwal bulls, libido had significant positive relationship with protrusion score, intensity of thrust and total time taken to successful ejaculation, whereas, Panwar and Nagpaul (1989) reported that libido had no correlation with total time to successful ejaculation in Karan Swiss, Karan Fries and Sahiwal breeds.

Erection score showed highly significant $(\mathrm{p}<0.01)$ positive correlation with protrusion score and intensity of thrust. Correlation of erection score with protrusion was medium (0.37), while it was low with intensity of thrust $(0.23)$. Protrusion score had highly significant positive medium correlation $(0.45)$ with intensity of thrust. Similar correlation of protrusion score with intensity of thrust was reported in Sahiwal bulls by Kumar (1995).

Intensity of thrust showed non-significant negative correlation with reaction time, total time and flehmen reaction. However, Kumar (1995) reported significant association of intensity of thrust with total time taken to successful ejaculation in Sahiwal bulls. Reaction time showed highly significant and very strong positive correlation $(0.82)$ with total time taken to successful ejaculation. This result corroborated with those reported by Kumar (1995) and Singh et al. (2015) in Sahiwal bulls. Further Flehmen reaction has very positive low correlation with all traits except protrusion and intensity of thrust.

Association study of the sexual behaviour traits revealed a very intense relationship and opened a new way to select/reject Kankrej breeding bulls. Kankrej bulls having better temperament and libido can be selected for semen collection. The significant positive correlation among the sexual behaviour traits like temperament, libido, and the intensity of thrust reflected the better harmony of sexual events taking place when the bull is exposed to the dummy (Soalnki et al. 2019). Overview of the results revealed the importance of sexual behaviour and their correlation with each other to design appropriate management strategies to maximize quality semen production from the individual bulls.

\section{Conclusions}

It was concluded that, Kankrej bull have good sexual behaviour throughout the year, however, sexual behaviour was more intensive in summer months. The bulls had very good temperament and were well managed during semen collection as they were handled carefully. Indigenous bulls are sexually sluggish and total time required to make breeding bulls donate quality ejaculates is more. It is, therefore, necessary to study the sexual behaviour of individual bulls critically to take corrective measures for successful semen collection. The correlation of various sexual behaviour traits reflected the importance of sexual behaviour in predicting the breeding value of bull and their future utility. The overview of the results depicted the need of greater emphasis on management interventions to improve sexual behaviour particularly libido and reaction time. The result emphasize the need of proper management of bulls and to improve their sexual behaviour especially libido score and reaction time.

\section{Acknowledgements}

The authors are grateful to the Director of Research, Sardarkrushinagar Dantiwada Agricultural University, Sardarkrushinagar, Gujarat for providing the necessary facilities to carry out this research work

\section{References}

Ahmad M, Asmat MT, Rehman N (2005) Relationship of testicular size and libido to age and season in Sahiwal bulls. Pak Vet J 25: 67-70

Anonymous (2017) Annual Progress Report (Jan. to Dec., 2016) Research Sub Committee on Animal Production. 13th Meeting held at SDAU Sardarkrushinagar Gujarat

Arthur, GH (1975) Veterinary Reproduction and Obstetrics, $4^{\text {th }}$ Ed, Bailliere Tindall, London

Asmat MT (2002) Studies on factors affecting the semen quality of Sahiwal bulls. M.Sc. Dissertation, Veterinary Animal Science University Lahore, Pakistan

Bhosrekar MR, Purohit JR, Gokhale SB, Mangurkar BR (1992a) Semen characteristics and behavioural pattern of buffalo bulls in relation to age and season. Indian J Anim Sci 62: 251-55

Bhosrekar MR, Purohit JR, Gokhale SB, Mangurkar BR (1992b) Effect of seasons on production performance of Surti buffalo bulls. Indian $\mathrm{J}$ Anim Sci 62: 443-47

Chenoweth PJ (1981) Libido and mating behavior in bulls, boars and rams: A review. Theriogenology 16: 155-77

Chenoweth PJ (1994) Bulls behavior, sex-drive and management. In: Fields $\mathrm{M}$ and Sand R (Ed) Factors Affecting Calf Crop, pp 319-30

Chenoweth PJ, Chase JRCC and Larsen RE (1996) The assessment of sexual performance in young Bos Taurus and Bos indicus beef bulls. App Anim Behav Sci 48: 225-36

Daniela SRB, Andre MJ, Gilberto PR, Francisco SW and Cristiana A(2008) Sexual behavior of zebu bulls and Angus at artificial insemination center. J Anim Sci R Fathoms Zootech 37: 121-23

Dias JC, Andrade VJ, Emerick LL, Martins JAM, Valefilho VRI, Silva MA (2009) Libido testing in young Guzerat bulls and their associations with reproductive traits and serum testosterone levels. Arch Vet Sci 14: 204-13

Duncan DB (1955) Multiple range and Multiple F-Tests. Biom 11: 1-42

Elrabie KA, Raina VS, Gupta AK, Mohanty TK (2008) Effect of semen collection floor on sexual behaviour and semen quality of Sahiwal bulls. Pak J Agri Sci 45: 201-05

Hearnshaw H and Morris CA (1984) Genetic and environmental effects on temperament score in beef cattle Aust J Agric Res 35:72333

Joshi VK, Kharche KG (1992) Assessment of sexual behaviour of crossbred bulls. Livest Advisor 17: 38-41

Kumar M, Nagpaul PK (1995) Assessment of sexual behaviour in Sahiwal and Murrah bulls. Indian J Anim Prod Mgmt 11: 217-21

Mahmood SA, Ijaz A, Ahmad N, Rehman HU, Zaneb H, Farooq U (2013) Studies on libido and serum testosterone concentration of Cholistani AI bulls under stress free and stressful seasons. J Anim Plant Sci 23: 1491-95

Mandal DK, Tyagi S (2004) Pre-copulatory behaviour of Sahiwal bulls during semen collection and effects of age and season on their sexual performance. Indian J Dairy Sci 57: 334-338 
Mandal DK, Nagpaul PK, Gupta AK (2000) Seasonal variation in seminal attributes and sexual behaviour of Murrah buffalo bulls. Indian J Dairy Sci 53: 278-83

Mandal DK, Tyagi S, Kumar M (2008) Sexual behaviour in Holstein Friesian $\times$ Sahiwal crossbred bulls. Indian Vet J 85: 636-39

Naskar S, Nagpaul PK (2005) Effect of social facilitation on seminal attributes and sexual behavior in crossbred male goats. Indian J Anim Prod Mangt 19: 103-08

National Research Council (1971) A guide to environmental research on animals. Natl Acad Sci, Washington

NBAGR (2018) National Bureau of Animal Genetic Resources. http:// 14.139.252.116/agris/brid Description.aspx accessed 15 November 2018

Pal A, Chatterjee PN and Chakravarty AK (2012) Genetic study of dairy cattle and buffalo bulls based on growth, milk production and reproductive traits, Iranian J Appl Anim Sci 2: 239-45

Panwar PS, Nagpaul PK (1989) Behaviour temperament and libido studies in KS bulls. Indian J Dairy Sci 42: 728-32

Patel VK, Chauhan HD, Pawar MM, Srivastava AK, Prajapati KB (2017) Effect of herbal galactogogue supplementation on production performance of lactating Kankrej cows. Int J Curr Microbiol Appl Sci $6: 2093-2098$
Prajapati KB, Nagpaul PK, Singh DV, Raina VS, Kale MM (1999) Effect of exercise on sexual behaviour of Mehsana buffalo bulls in different seasons. Indian J Dairy Sci 52: 100-103

Reddy MVB, Sasikala P (2013) Sexual behaviour of Sahiwal and Jerseyx Sahiwal bulls in tropical environments at villages of Chittor district. Int J Adv Sci Technol Res 3: 483-89

Sharma M, Bhat Y, Singh A, Sharma N, Rawat S (2017) Effect of Temperature Humidity Index on Semen Quality of Bovine Bull. Int J Curr Microbiol Appl Sci 6: 1822-1830

Singh S, Bhakat M, Mohanty TK, Kumar A, Gupta AK, Chakravarty AK, Singh P (2015) Sexual behaviour and its relationship with semen quality parameters in Sahiwal breeding bulls. Vet World 8: 745-749

Snedecor GW, Cochran WG (1994) Statistical Methods $7^{\text {th }}$ Ed Iowa State Univ Press, Ames pp 359-64

Solanki GB, Kavani FS, Talekar SH, Ahlawat AR, Savsani HH, Gamit PM (2019) Seasonal influence on sexual behaviour score of Gir bulls. Int J Curr Microbiol Appl Sci 8: 3100-3111

Srivastava AK, Singh C, Kumar P (2009) Influence of breed, sex, season, age, type of birth and birth weight on mortality rate in crossbred kids under stallfed conditions. Indian J Small Rumin 15: 156-162 